Original Research

\title{
Performance Investigation of a Nickel Cermet Anode Modified with Copper, Alkaline Earth Metal Oxide, Boron, and Perovskite for Direct Methane Fuel Cell
}

Andrew C. Chien ${ }^{1,2,}{ }^{*}$, Eric Y. Lin ${ }^{1}$, Nicole J. Ye ${ }^{1}$

1. Department of Chemical Engineering, Feng Chia University, Taichung 40724, Taiwan; E-Mails: cyinchien@fcu.edu.tw; a2321652@gmail.com; snoopy0302.0302@gmail.com

2. Green Energy Development Center, Feng Chia University, Taichung 40724, Taiwan

* Correspondence: Andrew C. Chien; E-Mail: cyinchien@fcu.edu.tw

Academic Editor: Robin T. White

Special Issue: In Situ and Operando Characterization of Hydrogen Fuel Cells

Journal of Energy and Power Technology

2021, volume 3 , issue 2

doi:10.21926/jept.2102024
Received: April 26, 2021

Accepted: June 01, 2021

Published: June 11, 2021

\begin{abstract}
The metallic copper, alkaline earth metal oxide, boron, and perovskite were incorporated on the surface of a Ni-cermet anode, and the performance of the modified Solid Oxide Fuel Cell (SOFC) anode was evaluated. The cell performance was analyzed by voltage-current characteristics ( $V$-I curve) and $\mathrm{H}_{2}-\mathrm{CH}_{4}$ step reactions ( $P$ - $t$ curve) in a potentiostatic mode. Besides, we also determined if a metallic phase or high electronic conductivity of the anode is important for a cell to perform well when $\mathrm{H}_{2}$ is used as a fuel, whereas both conductivity and anti-coking capability are critical while using $\mathrm{CH}_{4}$ as a fuel. The results showed that the anodes containing magnesium oxide $(\mathrm{MgO})$, lanthanum strontium titanate $\left(\mathrm{La}_{0.4} \mathrm{Sr}_{0.4} \mathrm{TiO}_{3-\gamma}\right)$, and boron were relatively resistant to the degradation in the $\mathrm{CH}_{4}$ environment when compared with others. The underlying mechanism varied mainly with electronic and structural promotion by the dopants as well as their material compatibility with the Ni-cermet substrate. These findings were evidenced and supported by surface analysis as well as in-situ infrared and mass spectroscopic studies too.
\end{abstract}

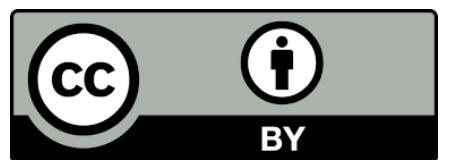

(C) 2021 by the author. This is an open access article distributed under the conditions of the Creative Commons by Attribution License, which permits unrestricted use, distribution, and reproduction in any medium or format, provided the original work is correctly cited. 


\section{Keywords}

Alkaline earth metal; boron; LST; SOFC; coking; infrared

\section{Introduction}

The conversion of methane $\left(\mathrm{CH}_{4}\right)$ into valuable chemicals or electric power is of continuous interest in both academia and industry because of surging global energy demands. Methane is the predominant component of natural gas, while to date, the widely adopted route for the conversion is still the conventional steam methane reforming (SMR) over nickel-based catalysts [1]. Due to the endothermic nature, the SMR reaction is highly energy-intensive, along with the need for large capital investment. As a result, a more economically feasible way is pursued to reduce the cost and increase energy efficiencies. Solid oxide fuel cells (SOFCs) have received much attention in the past decades for the conversion of hydrocarbons such as methane and biogas to electric power with high efficiencies. SOFCs are operated at high temperatures, where modest reaction kinetics could be achieved using nonprecious metal catalysts [2]. Nevertheless, irreversible deactivation remains the major challenge over the state-of-the-art Ni cermet anodes because of carbon deposition and sulfur poisoning when methane is used as a fuel.

Several approaches have been investigated to circumvent the degradation of $\mathrm{Ni}$ cermet anodes for the utilization of hydrocarbons in SOFCs [3-6]. Application of steam reforming reaction to the $\mathrm{Ni}$ cermet anode inside SOFCs was first proposed. However, the development of internal steam reforming was found to be hindered since a high ratio of steam/methane $(\mathrm{H} / \mathrm{C})$ was required to depress carbon accumulation. The high proportion of steam leads to dilution of fuel with low energy efficiency and adds to the complexity of heat management. In the past decade, various perovskites materials such as ( $\mathrm{LaSr})(\mathrm{CrMn}) \mathrm{O}_{3}$ [5], ( $\left.\mathrm{LaSr}\right) \mathrm{TiO}_{3}$ [7], $\mathrm{BaZrCeYYbO}_{3}$ [8], and $\mathrm{Sr}_{2} \mathrm{Mg}_{1-\mathrm{x}} \mathrm{Mn}_{\mathbf{x}} \mathrm{MoO}$ [9] have been considered as alternative anode materials with great interest. These ceramic anode materials did not only show improved tolerance to carbon deposition in $\mathrm{CH}_{4}$ but also presented good stability when subjected to redox cycles. However, cell performance with these anodes of Ni-free metal oxide was lower than those demonstrated by conventional Ni-cermet anode supported ones. The drawbacks were attributed to lack of active sites, low conductivity, material mismatch, and formation of undesirable phases $[10,11]$.

Surface modification or the addition of a protective top layer on the Ni-cermet anode is an effective method to avoid coking in Direct Methane Fuel Cells. Several groups and we have reported that adding a functional layer sustains a stable electrochemical performance of the Ni-cermet anode in $\mathrm{CH}_{4}$ [12-16]. The layer either functions as a catalyst to decompose $\mathrm{CH}_{4}$ or serves as a reforming zone for the conversion of oxidation products. In addition, the insertion efficacy of alkaline earth metal oxide on the Ni-cermet anode has also been demonstrated for the reduction in coking [1720]. The inclusion of basic oxides increases the Lewis basicity of the anode and allows chemisorption of oxidation products, including $\mathrm{H}_{2} \mathrm{O}$ and $\mathrm{CO}_{2}$, with subsequent reactions and removal of deposited carbon $[6,18,21,22]$. The content of basic oxide and the possible phase reaction in the anode composite have shown pronounced effects on the activity of methane oxidation and coking resistance. Nonetheless, the addition of basic oxides such as $\mathrm{CaO}, \mathrm{MgO}$, or $\mathrm{BaO}$ was effective in some studies, while the effects were not obvious in others [17, 19, 23]. Moreover, the addition of 
alkaline earth metal oxide to the anode is done through an impregnation method. Although the uniform distribution of the oxide particles can be achieved in the interstitial $\mathrm{Ni}$ sites by the wet method, the procedures could be tedious with multiple heating cycles.

On the other hand, the incorporation of rare-earth metal oxides and boron into a Ni-based catalyst resulted in a reduced coke formation [24-26]. Rare-earth metal oxides have been claimed to stabilize Ni particles on a catalyst support, acting as a structural promoter to improve the metal dispersion and to suppress the aggregation of Ni grains. The influence of boron on the activity and acidity of a catalyst has been known, mainly arising from better metal dispersion through structure control and metal-boron electronic interaction [27-29]. Nevertheless, no application of any boron promotor to a SOFC anode has been reported in the literature so far. In the present work, we modified the surface of a Ni-cermet anode with copper, alkaline earth metal oxide, boron, and perovskite via a solid-state reaction. The idea of using solid-state synthesis was motivated by the need to develop a simple way that can be adapted to current cell manufacturing methods such as tape-casting or die-pressing. The cell performance with these modified anodes was investigated by voltage-current characteristics and power density versus time in a potentiostatic mode. In situ surface analysis of these anodes was conducted by diffuse reflectance infrared spectroscopy (DRIFTs) to probe the mechanism responsible for coking resistance relevant to the electrode process in detail. The results obtained here gave a complementary study with those in literature and provided valuable information to design an effective anode material for fuel cell applications.

\section{Experimental}

\subsection{Material Synthesis}

All electrochemical tests were carried out on an electrolyte-supported SOFC. The cell was composed of electrolyte support (yttrium stabilized zirconia, 8 mol. $\% \mathrm{Y}_{2} \mathrm{O}_{3}$ doped in $\mathrm{ZrO}_{2}$ ), a cathode (Lanthanum strontium manganite, LSM), a cathode interlayer (LSM/YSZ, 50/50 wt.\%), an anode interlayer (NiO/YSZ, 50/50 wt.\%), and an anode (modified NiO/YSZ, 70/30 wt.\%). The composition of the modified NiO/YSZ anodes and their preparation is described below. The electrolytesupported cell was fabricated by die pressing. The electrolyte ( $4.5 \mathrm{~g}$ ), anode interlayer ( $2.5 \mathrm{~g})$, and anode ( $\sim 0.8 \mathrm{~g}$ ) were pressed (3000 psi) together in a die to form a half-cell, which was then sintered and calcined at $1400{ }^{\circ} \mathrm{C}$ for four hours. The cathode slurry consisting of LSM/YSZ and pure LSM was then screen printed on the electrolyte side of the sintered half-cell and calcined at 1200 ${ }^{\circ} \mathrm{C}$ for two hours. The obtained bottom cell was circular in shape with a diameter of about $2 \mathrm{~cm}$.

\subsection{Modification and Characterization of NiO/YSZ Anode}

Four types of modified NiO/YSZ anodes were prepared by incorporating metal, alkaline earth metal oxide, inorganic element, and perovskite. The metal modified anode was prepared by sputtering copper on the surface of the NiO/YSZ at a deposition rate of $3.5 \AA$ per second (Plasma treatment system, KD-SPUTTR). Two different sputtering times of 20 and 60 min were applied to obtain an estimated thickness of 420 and $1260 \mathrm{~nm}$, respectively. The other three materials were introduced by mixing an additive with NiO/YSZ in the anode layer (the amount was fixed at 1 wt.\% of the anode layer unless otherwise specified), followed by pressing and calcination to alter surface properties. The following additives were mixed with NiO/YSZ i) alkaline earth metal oxide: calcium 
hydroxide $\left(\mathrm{Ca}(\mathrm{OH})_{2}\right)$, calcium oxide $(\mathrm{CaO})$, and magnesium oxide $(\mathrm{MgO})$, ii) inorganic element: boric acid $\left(\mathrm{H}_{3} \mathrm{BO}_{3}\right)$, and boron powder (B), and iii) perovskite: lanthanum strontium titanate (LST, $\left.\mathrm{LaO}_{0.4 \mathrm{SrO}} .4 \mathrm{TiO}_{3}-\gamma\right)$. The LST powder was synthesized via a solid-state reaction $[30,31]$, whereas the boric acid was incorporated via a wet impregnation method. Briefly, boric acid was first dissolved in dilute nitric acid, added dropwise to the NiO/YSZ matrix, and then annealed in air at $500{ }^{\circ} \mathrm{C}$. The steps were repeated to achieve a loading of $1 \mathrm{wt} . \%$. Surface structure and morphology analysis were conducted by a scanning electron microscope (SN 4000).

\subsection{Electrical Performance}

Figure 1 shows the testing apparatus used in the study. The cell was assembled with two silver foils (as a current collector) and attached to one end of a ceramic tube by silver conductive paste (Alfa Aesar). The area of the layer of silver conductive paste on the cathode was about $1 \mathrm{~cm}^{2}$ and used as an active area for performance normalization. The cell was then placed in a furnace at room temperature and heated in a $\mathrm{He}$ (purity 99\%) stream. As the temperature arrived at $750{ }^{\circ} \mathrm{C}$, fuel gas ( 50 vol.\% $\mathrm{H}_{2}$ and $\mathrm{CH}_{4}$ diluted in $\mathrm{He}$ ) was introduced from the bottom of the tube to the anode, while the cathode was left exposed to air. The electrical performance of each cell was measured by its voltage-current $(V-I)$ curve using a potentiostat (VersaSTAT3-400). The comparison between the performances in $\mathrm{H}_{2}$ and $\mathrm{CH}_{4}$ was obtained by operating the cell in a potentiostatic mode and recording the output of the electric power.

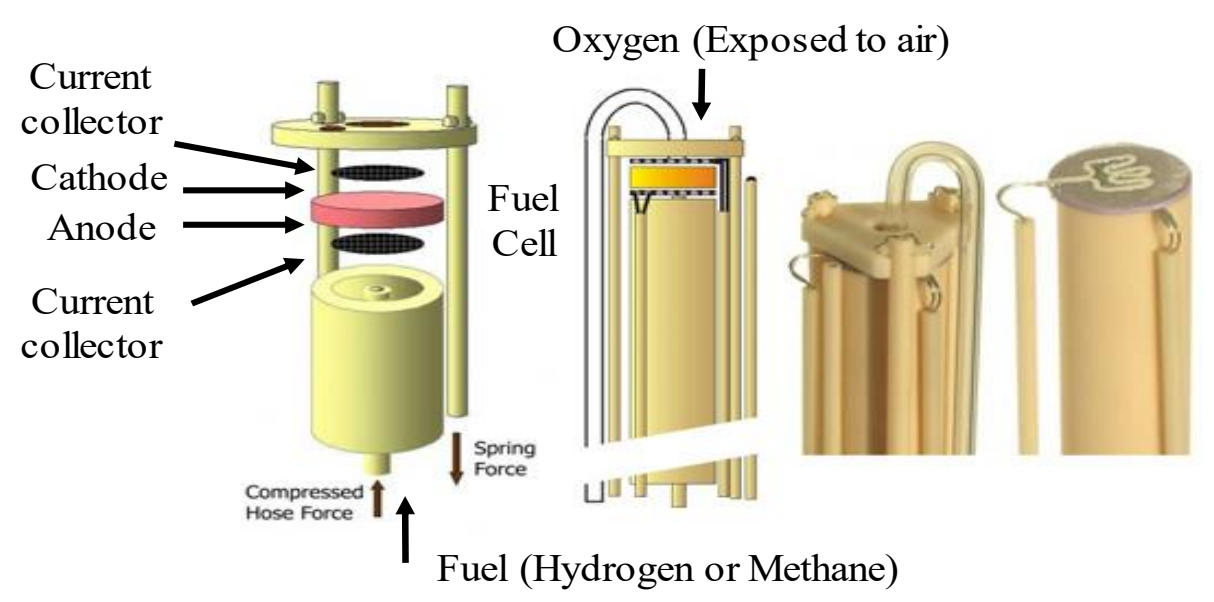

Figure 1 Schematic of a SOFC testing apparatus.

\subsection{In Situ Infrared Spectroscopy Studies}

Diffuse Reflectance Infrared Fourier Transform Spectroscopy (DRIFTs) was used to investigate the reaction mechanism and intermediates of $\mathrm{CH}_{4}$ oxidation on the modified NiO/YSZ anode. The IR spectra were collected by an IR spectrometer (Thermo Nicolet iS10) attached with a diffuse reflection accessory (the Praying Mantis ${ }^{\mathrm{TM}}$, Harrick). About $0.1 \mathrm{~g}$ of anode powder obtained after crushing and grinding the sintered anode disk was loaded into a high-temperature reaction chamber covered with a dome. The reactant gas containing $\mathrm{CH}_{4}(10 \mathrm{sccm})$ and $\mathrm{O}_{2}(2 \mathrm{sccm})$, both diluted with helium (50 sccm), was used without further purification. The composition of the reaction effluent from the DRIFTs reactor was monitored by a mass spectrometer (MS, Hiden Analytical, HPR 20). The 
mass/electron ratios (m/e) in the MS were selected for $\mathrm{H}_{2}(2), \mathrm{He}(4), \mathrm{CH}_{4}(15), \mathrm{H}_{2} \mathrm{O}$ (18), $\mathrm{CO}(28), \mathrm{O}_{2}$ (32), and $\mathrm{CO}_{2}$ (44). The MS response for $\mathrm{H}_{2}$ and $\mathrm{CO}$ was obtained by subtracting the $\mathrm{CH}_{4}$ fragment intensity from the total MS response at $\mathrm{m} / \mathrm{e}=2$, and subtracting the $\mathrm{CO}_{2}$ fragment intensity from the total MS response at $\mathrm{m} / \mathrm{e}=28$, respectively.

\section{Results and Discussion}

\subsection{Cell Performance in $\mathrm{H}_{2}$ and $\mathrm{CH}_{4}$}

The voltage and power density versus current density ( $V-I-P$ plot) characteristics curves of the four modified anodes in $\mathrm{H}_{2}$ at $800{ }^{\circ} \mathrm{C}$ are shown in Figure 2. The copper metal modified NiO/YSZ anode showed the best performance with a current density of $240 \mathrm{~mA} \mathrm{~cm}^{-2}$ and a power density of $50 \mathrm{~mW} \mathrm{~cm}^{-2}$. The cell performance improved as the time of coating was increased from 20 to 60 min. The alkaline earth metal oxide modified anode also showed an improved cell performance, except the $5 \mathrm{wt} . \% \mathrm{MgO}-\mathrm{Ni} / \mathrm{YSZ}$ one. For inorganic element modified anodes, the one impregnated with boric acid gave a higher current and power density, while an inferior performance was observed for the B-modified anode. Besides, the anode containing LST performed the worst among all in $\mathrm{H}_{2}$.

(a)

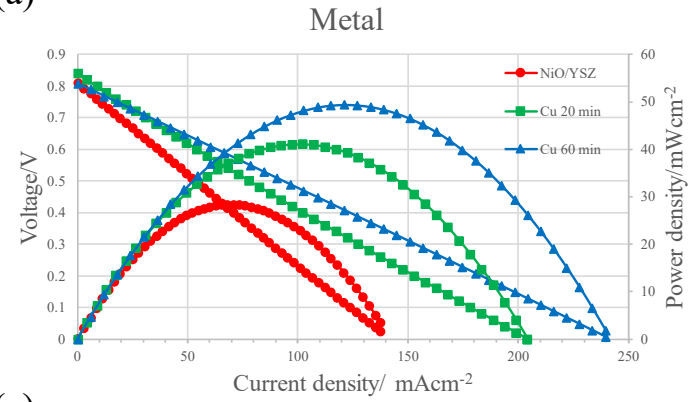

(c)

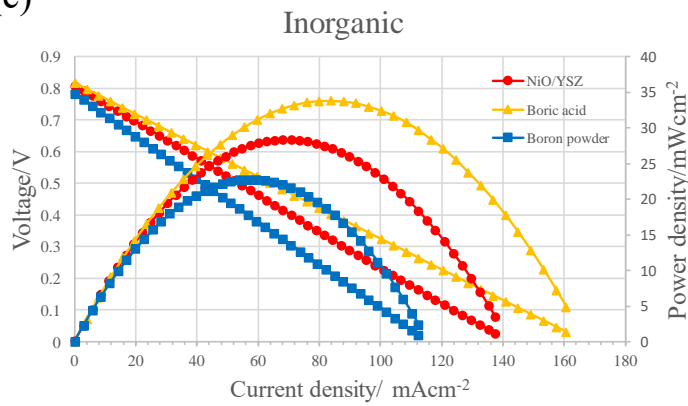

(b)

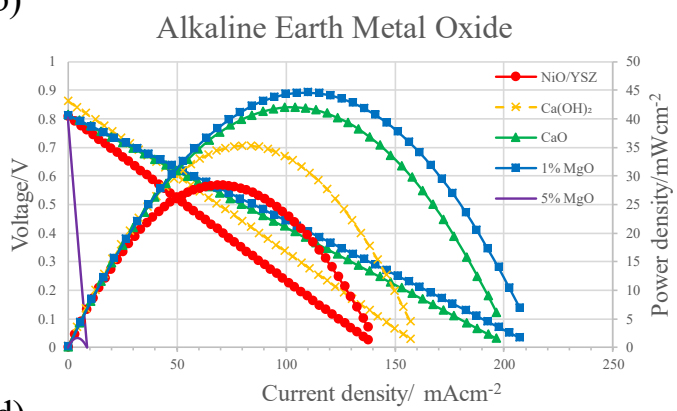

(d)

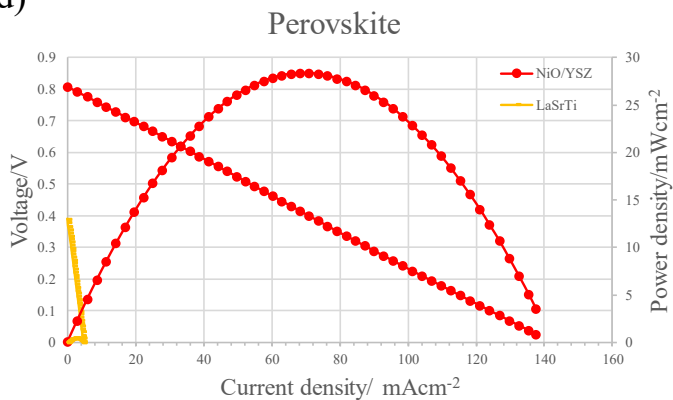

Figure 2 V-I-P plots of a SOFC with different modified anodes in $\mathrm{H}_{2}$ at $800^{\circ} \mathrm{C}$.

Figure 3 presents power density versus time ( $P$-t curve) characteristics of different anodes when the fuel was switched from $\mathrm{H}_{2}$ to $\mathrm{CH}_{4}$ in a potentiostatic mode. The results showed that the cells modified with $5 \mathrm{wt}$ \% $\mathrm{MgO}, \mathrm{LST}$, and $\mathrm{B}$ were relatively resistant to degradation in $\mathrm{CH}_{4}$. However, the one with $\mathrm{Cu}, \mathrm{CaO} / \mathrm{Ca}(\mathrm{OH})_{2}$, and $\mathrm{H}_{3} \mathrm{BO}_{3}$ showed no improvement in comparison with the pristine $\mathrm{NiO} / \mathrm{YSZ}$. In particular, the power density of the $5 \mathrm{wt} . \% \mathrm{MgO}$ and LST modified cells was found to increase drastically upon exposure to $\mathrm{CH}_{4}$. The enhancement in the cell performance probably resulted from the rapid reaction kinetics on the electrode in $\mathrm{CH}_{4}$ than that in $\mathrm{H}_{2}$. The activity of the anode and the cell performance were correlated and further studied with in situ IR spectroscopy. 
(a)

(c)
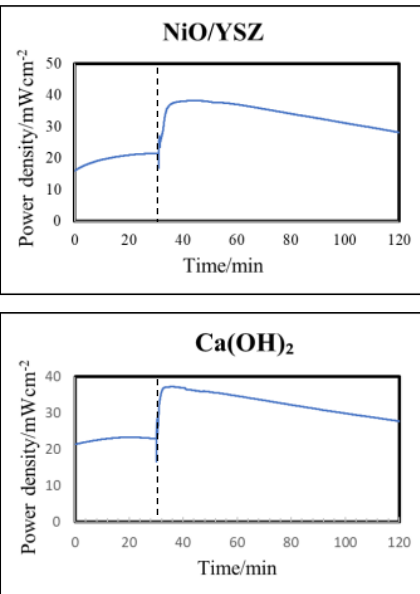

(e)

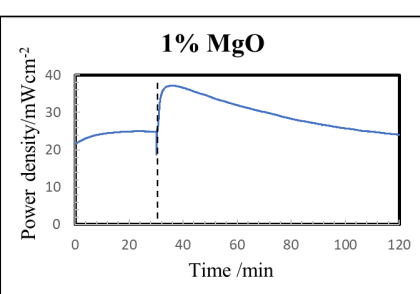

(g)

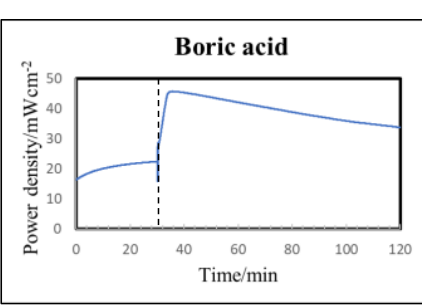

(b)

(d)

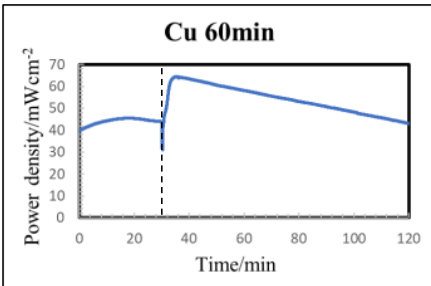

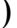

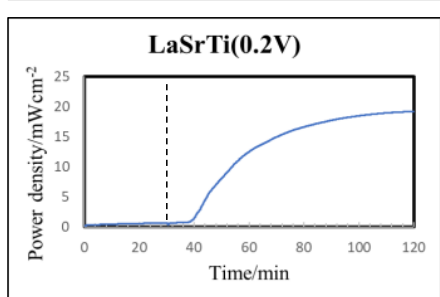

(f)

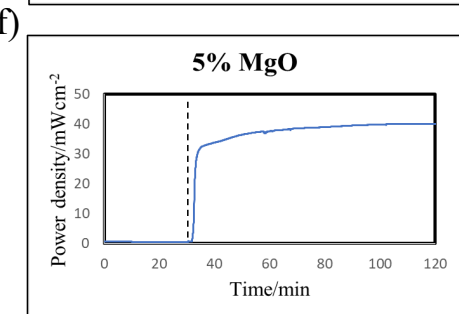

(h)

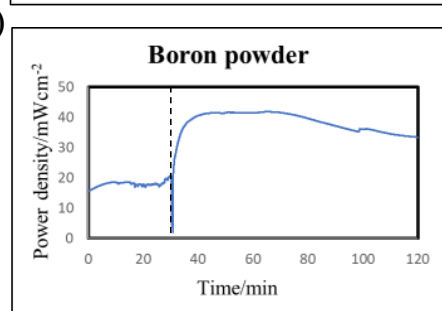

Figure 3 Power density vs. time ( $P$-t curve) curves of the modified anodes in a potentiostatic mode (at constant potential $=0.7 \mathrm{~V}$ unless specified), gas environment: 0-30 min in $\mathrm{H}_{2} / \mathrm{He}$ and 30-120 $\min$ in $\mathrm{CH}_{4} / \mathrm{He}$.

\subsection{In-Situ IR and Mass Spectroscopy}

Figure 4 depicts the DRIFTs spectra when the modified anodes were reduced in $\mathrm{H}_{2}$ at $700{ }^{\circ} \mathrm{C}$. The results showed that the reducibility of the anode followed an order of pristine $\mathrm{NiO} / \mathrm{YSZ}>$ boron $>$ LST > 5wt.\% MgO modified NiO/YSZ (from high to low). The extent of reduction was indicated by the intensity of the $\mathrm{Ni}-\mathrm{O}$ bond assigned with a band at $667 \mathrm{~cm}^{-1}$, which shifted down with a more reduced anode material as monitored during the reduction. The reducibility and the cell performance in $\mathrm{H}_{2}$ were found to be well correlated (Figure 2 and 4), indicating that high electrical performance was obtained for a more metallic or reduced anode. Figure 5 further illustrates the correlation with the $\mathrm{MgO}$ modified cell, demonstrating that the power density of the rarely reduced anode was low in $\mathrm{H}_{2}$, while the performance was enhanced when it was exposed to $\mathrm{CH}_{4}$. The reduction on the anode was manifested in $\mathrm{CH}_{4}$ due to the depletion of the $\mathrm{Ni}-\mathrm{O}$ bond as the corresponding $\mathrm{Ni}-\mathrm{O}$ band shifted continuously. However, it again shifted upward after introducing $\mathrm{O}_{2}$ flow over the $\mathrm{CH}_{4}$ exposed anode. Reversible band shifting confirmed the position of the Ni-O band as the redox reaction of $\mathrm{Ni}-\mathrm{NiO}$ occurred. 


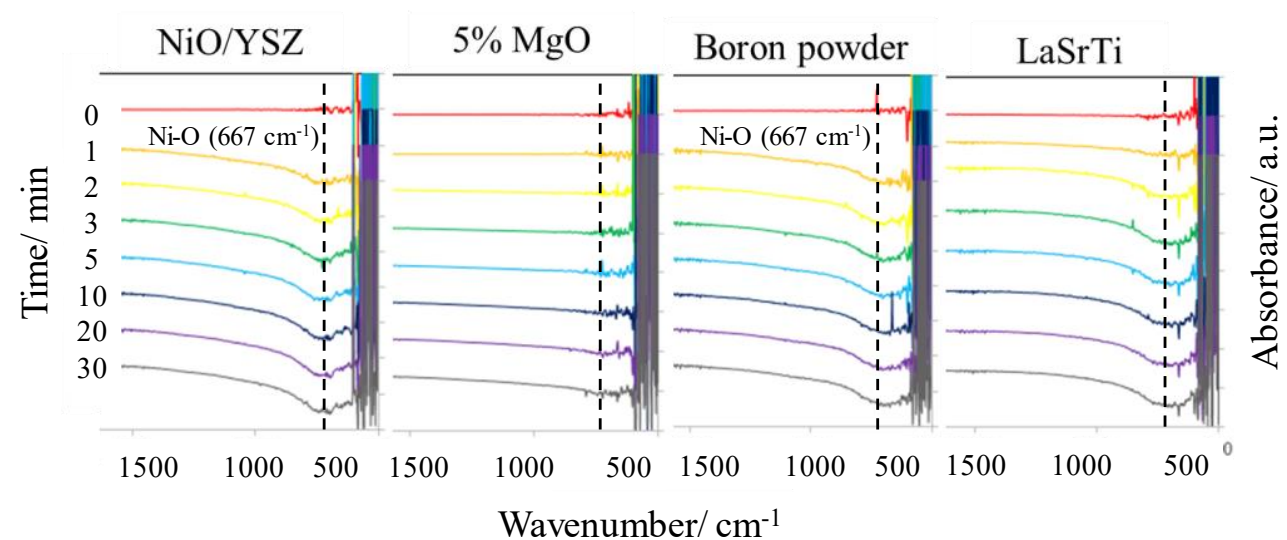

Figure 4 DRIFTs spectra of modified anodes on reduction in $\mathrm{H}_{2}$ at $700{ }^{\circ} \mathrm{C}$.

(a)

(b)
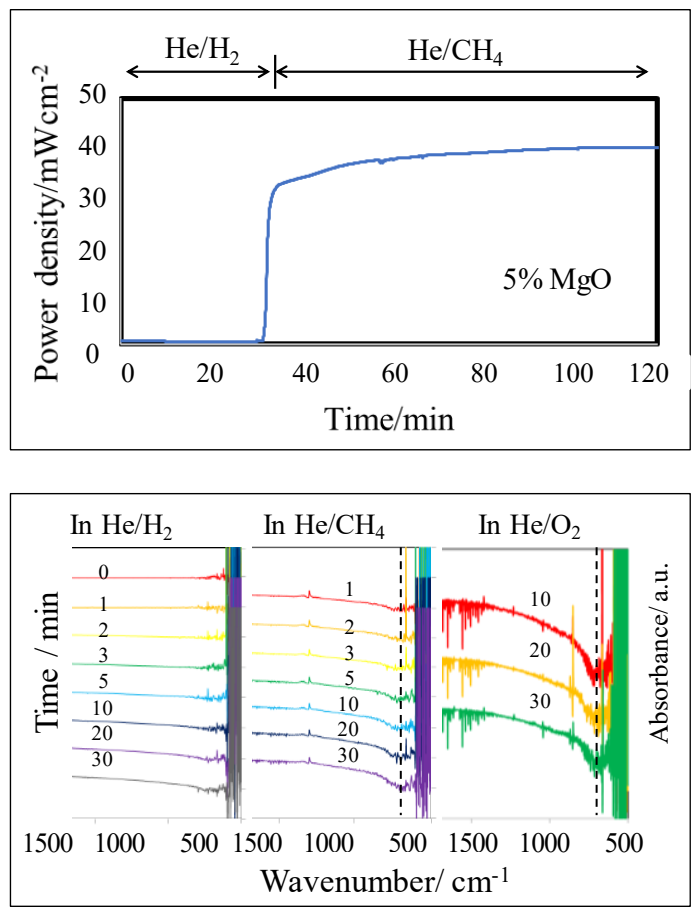

Figure 5 a) P-t curve of 5 wt.\% MgO-NiO/YSZ anode and b) DRIFTs spectra of the anode subjected to various gas atmospheres, including $\mathrm{H}_{2}, \mathrm{CH}_{4}$, and $\mathrm{O}_{2}$ at $700{ }^{\circ} \mathrm{C}$.

The MS profiles of the eluting gaseous species produced on the modified anode upon exposure to $\mathrm{CH}_{4}$ are shown in Figure 6. The results showed that the syngas, i.e., $\mathrm{H}_{2}$ and $\mathrm{CO}$ were the major gaseous products formed on all the anode materials. The $\mathrm{H}_{2}$ production followed a consistently increasing trend with the electrochemical performance in $\mathrm{CH}_{4}$ (Figure 3 vs. Figure 6). Among all, the $5 \mathrm{wt} . \% \mathrm{MgO}$ modified anode gave the best cell performance along with stable syngas production. The molar ratio of $\mathrm{H}_{2}$ to $\mathrm{CO}$ in the syngas was about 2 to 1 , implying that the primary reaction engaged partial oxidation of methane. Besides, the rapid decrease in the concentration of $\mathrm{CO}_{2}$ and $\mathrm{H}_{2} \mathrm{O}$ suggested the involvement of a secondary reaction, consuming these by-products. 

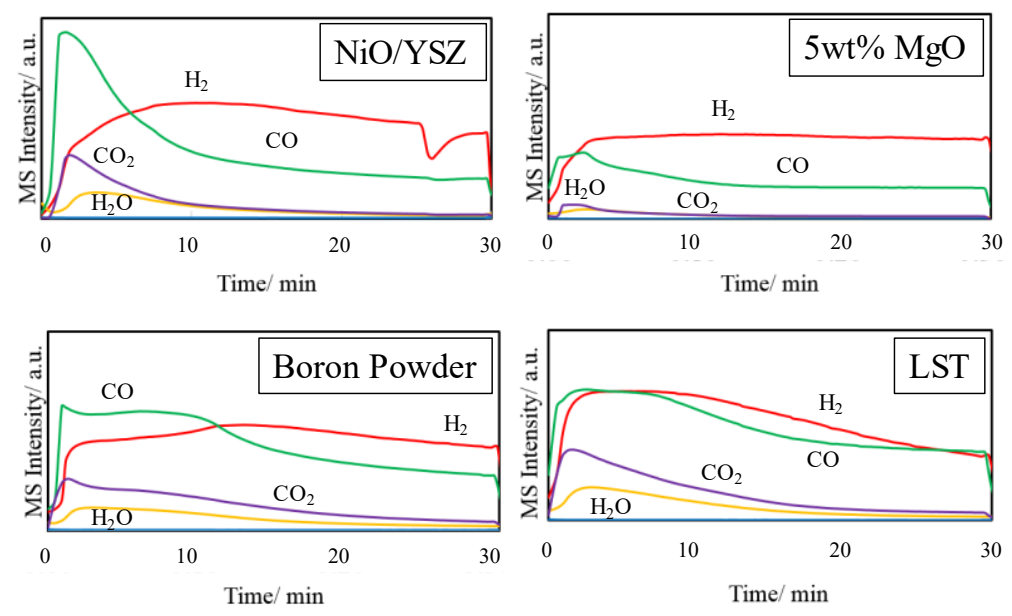

Figure $6 \mathrm{MS}$ profiles of gaseous products formed on the pristine and modified $\mathrm{NiO} / \mathrm{YSZ}$ anodes exposed to $\mathrm{CH}_{4}$ at $700{ }^{\circ} \mathrm{C}$.

The above experimental results demonstrated that the cell performance of the modified anodes was strongly influenced by the type of additives and the resultant properties. The $V-I-P$ results showed that electrical conductivity played a major role in the cell performance in $\mathrm{H}_{2}$. The cell with the Cu-modified anode exhibited the highest power density, followed by $\mathrm{MgO}, \mathrm{CaO}, \mathrm{B}$, and LST modified anodes. Compared with metallic $\mathrm{Cu}$, basic metal oxide exhibited low electrical conductivity, thus, leading to lower cell performance. Electrical conductivity investigated for various basic oxide modified Ni/SDC cermets followed an order of $\mathrm{CaO}>\mathrm{SrO}>\mathrm{MgO}>\mathrm{BaO}>\mathrm{La}_{2} \mathrm{O}_{3}[20]$. On the contrary, in the current study, the $\mathrm{MgO}$ modified cell performed slightly better than the $\mathrm{CaO}$ modified one. This was probably because the comparison was made for different electrolytes (SDC vs. YSZ), and an inconsistent amount of dopant was used. Additionally, alkaline earth metal oxides such as $\mathrm{CaO}$ were reported to dissolve easily in the lattice of fluorite structures, thus, impeding the oxide ion conductivity of the anode. Therefore, the amount of loading needs optimization for different systems due to the diverse results reported in the literature [17, 20].

Apart from $\mathrm{Cu}$ and basic metal oxides, the addition of $\mathrm{B}$ or LST to the anode showed no improvement in cell performance in $\mathrm{H}_{2}$. Boron has been shown promoting $\mathrm{Ni}$-based catalysts for steam reforming of hydrocarbons; however, doping of boron precursors might incur a problem of poisoning or material incompatibility in the electrode [32]. The YSZ electrolyte is reported to react with volatile boron species above $600{ }^{\circ} \mathrm{C}$ to form $\mathrm{YBO}_{3}$, disintegrating the electrode structure. This explains the reason behind using the wet method to introduce boric acid rather than solid-state reaction adopted for other compounds studied in this work. In 'fact, trials with the solid-state reaction using boric acid have been failed. Besides, the addition of LST also suffered from the material mismatch with the NiO/YSZ anode, although it was not very drastic. Moreover, the LST possesses low oxide ion conductivity and poor catalytic activity toward $\mathrm{H}_{2}$ oxidation due to large polarization resistance $[33,34]$.

Despite the poor activity of 5 wt.\% MgO, B, and LST modified anodes in $\mathrm{H}_{2}$, these modified cells performed better than their counterparts in $\mathrm{CH}_{4}$. The improved performance of the $5 \mathrm{wt} . \% \mathrm{MgO}$ modified anode was attributed to increased electrochemical activity and coking tolerance of the $\mathrm{Ni}$ metal. Since $\mathrm{CH}_{4}$ exhibits higher reducing strength than $\mathrm{H}_{2}$, the anode ( $\mathrm{MgO}-\mathrm{NiO}$ ) could be partially transformed to a metallic $\mathrm{Ni}$ phase (or $\mathrm{Ni}_{x} \mathrm{Mg}_{1-\mathrm{x}} \mathrm{O}$ ) $[35,36]$. The $\mathrm{Ni}$ phase would then form a 
percolating layer on the YSZ electrolyte through the anode matrix and may improve the electrode conductivity. Besides, the $\mathrm{Ni}$ metal provides the active sites to dissociate $\mathrm{CH}_{4}$, thus, facilitating subsequent oxidation reaction. The presence of $\mathrm{MgO}$ altered the phase of $\mathrm{Ni}$ from metallic to cationic and made the anode reluctant to reduction as observed in the DRIFTs experiment, thereby alleviating deactivation of the $\mathrm{Ni}$ active site by coking. It was also noticed that a lot of carbon deposit was found around the $\mathrm{MgO}$ modified anode and near current collectors after the test in comparison with the $\mathrm{CaO}$ modified one. The inclusion of $\mathrm{CaO}$, a basic metal oxide, in the Ni-cermet anode has been demonstrated to reduce the deactivation in $\mathrm{CH}_{4}$ too. However, no such improvement was observed in the current study [20]. The likely reason was explained based on different preparation methods. The anode made by the wet impregnation might give a homogeneous distribution of precursors than that by the solid-state reaction. Furthermore, the amount of $\mathrm{MgO}$ in the anode was critical for cell performance since the addition of $5 \mathrm{wt} . \% \mathrm{MgO}$ sustained the $\mathrm{Ni}$ cermet anode in $\mathrm{CH}_{4}$ while the one with $1 \mathrm{wt} . \% \mathrm{MgO}$ was not effective. Nevertheless, high MgO content would give a poor performance in $\mathrm{H}_{2}$ due to a reduced electrical conductivity $[19,36]$. In contrast to the electronic promotion of $\mathrm{MgO}$ and boron, LST seemed to act as a structure promotor, and their additions greatly changed the morphologies of the Ni cermet anode, as shown in Figure 7. In the case of NiO/YSZ in combination with LST, a barrier layer was formed to cover the proximity of Ni cermet, thus, retarding the diffusion of $\mathrm{CH}_{4}$ and the succeeding activation. Slowing down the bond scission of methane would promote the oxidation of deposited carbon. Also, the effect of promotion was not evident in the composite anode of boron and Ni-cermet, possibly due to the material mismatch between boron species and YSZ electrolyte.
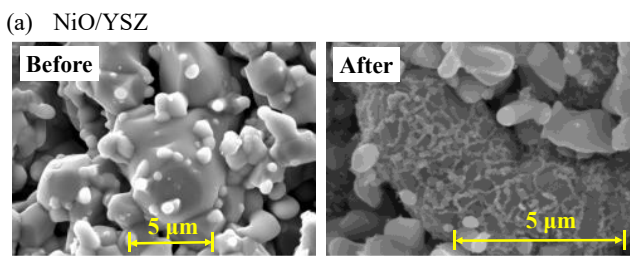

(b) Boron doped $\mathrm{NiO} / \mathrm{YSZ}$

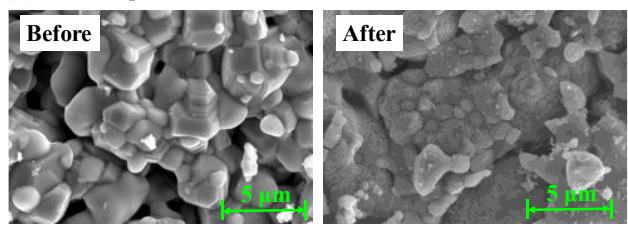

(c) $5 \mathrm{wt} \% \mathrm{MgO}$ doped $\mathrm{NiO} / \mathrm{YSZ}$

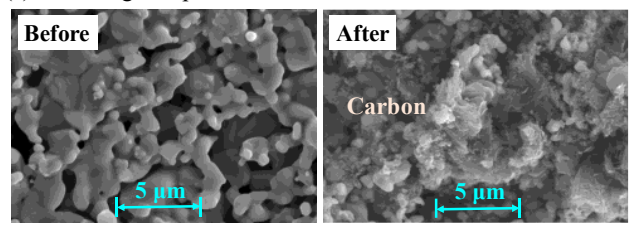

(d) LST doped $\mathrm{NiO} / \mathrm{YSZ}$
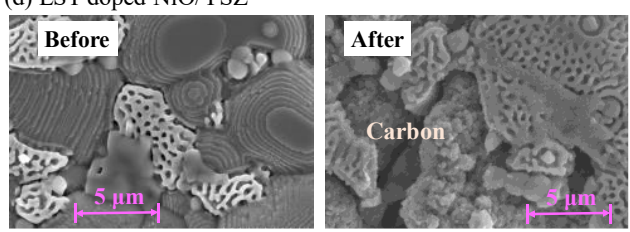

Figure 7 SEM images of the surface of pristine and modified $\mathrm{Ni}$ cermet anodes before/after cell test in $\mathrm{CH}_{4}$. 


\section{Conclusions}

In summary, we modified the surface of a Ni-cermet anode with copper, alkaline earth metal oxide, boron, and perovskite and investigated the cell performance in SOFCs. The results indicated that the copper modified anode gave the best performance in $\mathrm{H}_{2}$, while the one incorporated with inorganic compounds such as $\mathrm{MgO}$, LST, and boron behaved relatively stable in $\mathrm{CH}_{4}$. The cell performance of the modified anodes was greatly affected by the interaction between the dopant and the Ni cermet, as well as the material compatibility with the substrate. The promotion of Nicermet anodes by $\mathrm{MgO}$ worked mainly via electronic interaction with $\mathrm{Ni}$, while in LST and boron, it did through structure control. Meanwhile, the modification with $\mathrm{CaO}$ was not effective, probably due to the non-uniform distribution of precursors resulted from the solid-state reaction. Our studies provided valuable information to compare the effect of different dopants on the $\mathrm{Ni}$ anode and to obtain the underlying mechanism for coking resistance by an in situ surface analysis. This will allow designing an effective material capable of withstanding methane and other hydrocarbons for fuel cells and other potential energy-related applications.

\section{Acknowledgments}

The authors would like to acknowledge the financial support from Feng Chia University and from National Science Council of Taiwan under contract MOST 106-2218-E-035-009-MY2. The authors also gave the gratitude to lab colleagues, Mr. Willy C. Chen and Brian Y. Liao, for replotting the figures and preparing LST powders, respectively.

\section{Author Contributions}

Andrew C. Chien - Project management, experimental design, manuscript writing; Eric Y. Lin Cell fabrication, electrical measurement, surface analysis; Nicole J. Ye - IR and MS analysis

\section{Competing Interests}

The authors have declared that no competing interests exist.

\section{References}

1. Bharadwaj SS, Schmidt LD. Catalytic partial oxidation of natural gas to syngas. Fuel Process Technol. 1995; 42: 109-127.

2. You HX, Abuliti A, Ding XW, Zhou YH. Reactions of low and middle concentration dry methane over Ni/YSZ anode of solid oxide fuel cell. J Power Sources. 2007; 165: 722-727.

3. Rismanchian A, Mirzababaei J, Chuang SS. Electroless plated Cu-Ni anode catalyst for natural gas solid oxide fuel cells. Catal Today. 2014; 245: 79-85.

4. Boldrin P, Ruiz-Trejo E, Mermelstein J, Menéndez JM, Reina TR, Brandon NP. Strategies for carbon and sulfur tolerant solid oxide fuel cell materials, incorporating lessons from heterogeneous catalysis. Chem Rev. 2016; 116: 13633-13684.

5. Shu LN, Sunarso J, Hashim SS, Mao JK, Zhou W, Liang FL. Advanced perovskite anodes for solid oxide fuel cells: A review. Int J Hydrogen Energy. 2019; 44: 31275-31304. 
6. Yue WX, Li YF, Zheng $\mathrm{Y}, \mathrm{Wu} \mathrm{T}$, Zhao $\mathrm{CH}$, Zhao J, et al. Enhancing coking resistance of $\mathrm{Ni} / \mathrm{YSZ}$ electrodes: In situ characterization, mechanism research, and surface engineering. Nano Energy. 2019; 62: 64-78.

7. Jung I, Lee D, Lee SO, Kim D, Kim J, Hyun SH, et al. LSCM-YSZ nanocomposites for a high performance SOFC anode. Ceram Int. 2013; 39: 9753-9758.

8. Yang L, Wang SZ, Blinn K, Liu MF, Liu Z, Cheng Z, et al. Enhanced sulfur and coking tolerance of a mixed ion conductor for SOFCs: $\mathrm{BaZr}_{0.1} \mathrm{Ce}_{0.7} \mathrm{Y}_{0.2-\mathrm{x}} \mathrm{Yb}_{\mathrm{x}} \mathrm{O}_{3-\delta}$. Science. 2009; 326: 126-129.

9. Huang YH, Dass RI, Xing ZL, Goodenough JB. Double perovskites as anode materials for solidoxide fuel cells. Science. 2006; 312: 254-257.

10. Hao XM, Han DD, Wang JW, Liu YJ, Rooney D, Sun W, et al. Co-tape casting fabrication, field assistant sintering and evaluation of a coke resistant supported solid oxide fuel cell. Int J Hydrogen Energy. 2015; 40: 12790-12797.

11. Fisher JC, Chuang SS. Investigating the $\mathrm{CH}_{4}$ reaction pathway on a novel LSCF anode catalyst in the SOFC. Catal Commun. 2009; 10: 772-776.

12. Chien $A C$, Lin $E Y$, Lai AD. Aid of a metallic functional layer on $\mathrm{Ni} / \mathrm{YSZ}$ anode for direct methane fuel cell. Int J Hydrogen Energy. 2020; 45: 23526-23532.

13. Zhan ZL, Lin YB, Pillai M, Kim I, Barnett SA. High-rate electrochemical partial oxidation of methane in solid oxide fuel cells. J Power Sources. 2006; 161: 460-465.

14. Wang W, Su C, Wu YZ, Ran R, Shao ZP. A comprehensive evaluation of a $\mathrm{Ni}_{-} \mathrm{Al}_{2} \mathrm{O}_{3}$ catalyst as a functional layer of solid-oxide fuel cell anode. J Power Sources. 2010; 195: 402-411.

15. Hua B, Li M, Luo JL, Pu J, Chi B, Li J. Carbon-resistant Ni- $\mathrm{Zr}_{0.92} \mathrm{Y}_{0.08} \mathrm{O}_{2-\delta}$ supported solid oxide fuel cells using $\mathrm{Ni}-\mathrm{Cu}-\mathrm{Fe}$ alloy cermet as on-cell reforming catalyst and mixed methane-steam as fuel. J Power Sources. 2016; 303: 340-346.

16. Wang ZQ, Wang ZB, Yang WQ, Peng RR, Lu YL. Carbon-tolerant solid oxide fuel cells using $\mathrm{NiTiO}_{3}$ as an anode internal reforming layer. J Power Sources. 2014; 255: 404-409.

17. Asamoto M, Miyake S, Sugihara K, Yahiro H. Improvement of Ni/SDC anode by alkaline earth metal oxide addition for direct methane-solid oxide fuel cells. Electrochem Commun. 2009; 11: 1508-1511.

18. Yang L, Choi YM, Qin WT, Chen HY, Blinn K, Liu M, et al. Promotion of water-mediated carbon removal by nanostructured barium oxide/nickel interfaces in solid oxide fuel cells. Nat Commun. 2011; 2: 1-9.

19. Yang Q, Chai FT, Ma C, Sun CW, Shi SQ, Chen LQ. Enhanced coking tolerance of a MgO-modified $\mathrm{Ni}$ cermet anode for hydrocarbon fueled solid oxide fuel cells. J Mater Chem A. 2016; 4: 1803118036.

20. Qu JF, Wang W, Chen YB, Deng X, Shao ZP. Stable direct-methane solid oxide fuel cells with calcium-oxide-modified nickel-based anodes operating at reduced temperatures. Appl Energy. 2016; 164: 563-571.

21. Han ZY, Yang YR, Kong DX. Surface-scale affinity and adsorption selectivity of alkaline earth metal oxides to $\mathrm{H}_{2} \mathrm{O}$ and $\mathrm{CO}_{2}$ : Insight into SOFC anode modification. Appl Surf Sci. 2020; 503: 144333.

22. Li XX, Liu MF, Lai SY, Ding D, Gong MY, Lee JP, et al. In situ probing of the mechanisms of coking resistance on catalyst-modified anodes for solid oxide fuel cells. Chem Mater. 2015; 27: 822828. 
23. Takeguchi T, Kani Y, Yano T, Kikuchi R, Eguchi K, Tsujimoto K, et al. Study on steam reforming of $\mathrm{CH}_{4}$ and $\mathrm{C}_{2}$ hydrocarbons and carbon deposition on Ni-YSZ cermets. J Power Sources. 2002; 112: 588-595.

24. Chen L, Lu Y, Hong $Q$, Lin J, Dautzenberg FM. Catalytic partial oxidation of methane to syngas over Ca-decorated-Al $\mathrm{O}_{3}$-supported $\mathrm{Ni}$ and $\mathrm{NiB}$ catalysts. Appl Catal A Gen. 2005; 292: 295-304.

25. Xu J, Saeys M. Improving the coking resistance of Ni-based catalysts by promotion with subsurface boron. J Catal. 2006; 242: 217-226.

26. Zhou XW, Yan N, Chuang KT, Luo JL. Progress in La-doped $\mathrm{SrTiO}_{3}$ (LST)-based anode materials for solid oxide fuel cells. RSC Adv. 2014; 4: 118-131.

27. Bu KK, Deng J, Zhang XY, Kuboon S, Yan TT, Li HR, et al. Promotional effects of B-terminated defective edges of $\mathrm{Ni} /$ boron nitride catalysts for coking- and sintering-resistant dry reforming of methane. Appl Catal B Environ. 2020; 267: 118692.

28. Chien AC, Van Bokhoven JA. Boron nitride coated rhodium black for stable production of syngas. Catal Sci Technol. 2015; 5: 3518-3524.

29. Singh S, Nguyen TD, Siang TJ, Phuong PT, Huy Phuc NH, Truong QD, et al. Boron-doped Ni/SBA15 catalysts with enhanced coke resistance and catalytic performance for dry reforming of methane. J Energy Inst. 2020; 93: 31-42.

30. Neagu D, Irvine JT. Structure and properties of $\mathrm{La}_{0.4} \mathrm{Sr}_{0.4} \mathrm{TiO}_{3}$ ceramics for use as anode materials in solid oxide fuel cells. Chem Mater. 2010; 22: 5042-5053.

31. Savaniu CD, Irvine JT. Reduction studies and evaluation of surface modified A-site deficient Ladoped $\mathrm{SrTiO}_{3}$ as anode material for IT-SOFCs. 2009; 19: 8119-8128.

32. Chen K, Ai N, Jiang SP. Chemical compatibility between Boron oxides and electrolyte and cathode materials of solid oxide fuel cells. Fuel Cells. 2013; 13: 1101-1108.

33. Lee S, Kim J, Vohs JM, Gorte RJ. SOFC anodes based on infiltration of $\mathrm{La}_{0.3} \mathrm{Sr}_{0.7} \mathrm{TiO}_{3}$. J Electrochem Soc. 2008; 155: B1179.

34. Lee MJ, Shin JH, Ji MJ, Hwang HJ. Fabrication and electrochemical performance of nickel- and gadolinium-doped ceria-infiltrated $\mathrm{La}_{0.2} \mathrm{Sr}_{0.8} \mathrm{TiO}_{3}$ anodes for solid oxide fuel cells. J Power Sources. 2018; 374: 181-187.

35. Liu Y, Bai YH, Liu J. ( $\left.\mathrm{Ni}_{0.75} \mathrm{Fe}_{0.25-x} \mathrm{MgO}\right) / \mathrm{YSZ}$ anode for direct methane solid-oxide fuel cells. J Power Sources. 2011; 196: 9965-9969.

36. Shiratori $\mathrm{Y}$, Sasaki K. NiO-ScSZ and $\mathrm{Ni}_{0.9} \mathrm{Mg}_{0.1} \mathrm{O}-\mathrm{ScSZ}$-based anodes under internal dry reforming of simulated biogas mixtures. J Power Sources. 2008; 180: 738-741. 
JEPT 2021; 3(2), doi:10.21926/jept.2102024

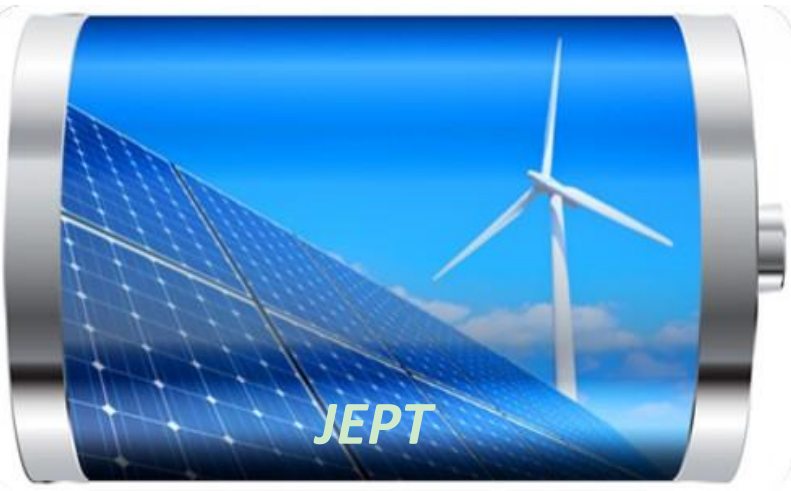

Enjoy JEPT by:

1. Submitting a manuscript

2. Joining in volunteer reviewer bank

3. Joining Editorial Board

4. Guest editing a special issue

For more details, please visit:

http://www.lidsen.com/journal/jept 